\title{
The Long Shadow of Agrarian Conflict: Agrarian Inequality and Voting in Spain
}

\author{
Jordi Domènech ${ }^{1}\left(\right.$ i) and Ignacio Sánchez-Cuenca ${ }^{2 *}$ (1) \\ ${ }^{1}$ Department of Social Sciences, Universidad Carlos III de Madrid, Madrid, Spain; and ${ }^{2}$ Carlos III-Juan March Institute of \\ Social Sciences, Universidad Carlos III de Madrid, Madrid, Spain \\ * Corresponding author. Email: igsanche@clio.uc3m.es
}

(Received 6 October 2020; revised 17 March 2021; accepted 21 June 2021; first published online 9 November 2021)

\begin{abstract}
This article studies the persistent effects of past agrarian inequality on contemporary voting preferences. Although Western European countries became industrial (and later post-industrial) economies, the political effects of the agrarian cleavage are still visible in those countries in which the agrarian issue was dominant in the interwar period (the industrial laggards). Looking at the spatial variation in voting patterns in the fifteen elections held in Spain since 1977, we show through mediation analysis that areas with high historical agrarian inequality have higher levels of leftist vote. We examine two transmission channels: one economic (related to backwardness); the other political (related to family transmission of political allegiances). A survey analysis provides evidence in favour of family transmission. A brief exploration of other cases confirms the general argument: a similar effect is found in Italy (an industrial laggard), but not in England (an early industrializer).
\end{abstract}

Keywords: agrarian inequality; cleavage; interwar Europe; elections; the Left; land reform; Spain

The historical and geographical persistence of patterns of political behaviour has been well documented (see, among others, Acharya, Blackwell and Sen 2016b; Charnysh 2015; Homola, Pereira and Tavits 2020; Lupu and Peisakhin 2017; Rodden 2019; Sanchez-Cuenca 2019; Tilley 2015; Voigtländer and Voth 2012; Wittenberg 2006). In many cases, the phenomenon of political persistence is conceptualized as a historical legacy, where the effect of an extinct cause survives vast economic, social and political transformations (Simpser, Slater and Wittenberg 2018).

We contribute to this line of research by investigating the long-term effects of agrarian inequality in interwar Europe. According to the classical theory on cleavage formation (Lipset and Rokkan 1967), the modern system of cleavages was formed in the 1920s and 1930s with the generalization of universal male suffrage and the advent of mass politics. Following Bartolini (2000), we argue that in countries in which the economy was still heavily agrarian and there was extreme inequality, landless labourers developed strong preferences for the Left that have survived. Lipset and Rokkan (1967) argued that the interwar system of cleavages 'froze' and determined party competition for many decades to come. We revisit the 'freezing hypothesis' from the perspective of historical legacies, arguing that the political effects of agrarian inequality survived industrialization (Tilley [2015] makes a similar argument regarding the religious cleavage).

Spain constitutes an optimal case to study the long-term effects of agrarian inequality. According to Simpson and Carmona (2020), land reform and land-related conflict were the main triggers of the collapse of the Second Republic and the posterior Civil War (1936-39). When democracy was reinstated in 1977, agrarian conflict had been largely defused (Linz and Montero 2001, 176). Despite Franco's long authoritarian spell, we nonetheless find a strong

(C) The Author(s), 2021. Published by Cambridge University Press. This is an Open Access article, distributed under the terms of the Creative Commons Attribution licence (https://creativecommons.org/licenses/by/4.0/), which permits unrestricted re-use, distribution, and reproduction in any medium, provided the original work is properly cited. 
and robust effect of pre-Civil War agrarian inequality on support for the Left in contemporary Spain (1977-2019). In areas in which there was a greater concentration of landless labour, support for the Left is higher many decades later.

We posit the existence of two, non-exclusive causal channels that account for the persistence of the effects of agrarian inequality. First, land-related conflicts generated enduring political identities and loyalties based on memories of deprivation and repression that were transmitted generationally. Secondly, agrarian inequality had long-term economic consequences (backwardness, poverty and low human capital) that brought about favourable conditions for a strong leftist orientation in society's poorest strata. These channels are different from that envisaged by Rodden (2019) in his analysis of the persistent geographical patterns of support for the Democratic Party in the US: industrial workers who lived in urban centres and voted for the Democratic Party were replaced in the post-industrial period by poor people who also voted for the Democrats.

We have collected several indicators of historical agrarian inequality at the provincial and municipal levels. No matter what indicator of agrarian inequality we use, we find a systematic effect: the greater the level of inequality, the higher the support for the Left decades later. To avoid concerns about measurement issues, we confirm these results by instrumenting agrarian inequality with the pace of the Reconquest between the eighth and fifteenth centuries. The results do not change.

To estimate the strength of the two mechanisms of transmission (the political and the economic), we use sequential g-estimation to control for potential post-treatment bias (Acharya, Blackwell and Sen 2016a). Although action takes place through the economic channel, the political channel seems to be more significant. Regarding the latter, we argue that leftist political identities survived under the dictatorship thanks to family socialization. The analysis of a unique Spanish survey with information about respondents' ideology, their parents' ideology and the side the family took during the Civil War provides suggestive evidence in favour of the family transmission mechanism.

According to the theoretical argument, the historical legacy of agrarian conflict should be observable in countries that were industrial laggards in the interwar period and had high levels of agrarian inequality. A brief exploration of the Italian and English cases confirms this pattern: both countries had extreme agrarian inequality, but Italy was a late industrializer and England an early one. The exploratory evidence we provide shows that Italy is very similar to Spain, with greater support for the Left in regions with more landless peasants, whereas the effect does not exist or is negative in the case of England. This comparative analysis helps to delimit the scope conditions of the main hypothesis.

The article is structured as follows. The first section presents the general hypothesis about the political consequences of agrarian inequality. The second section provides the historical background of the agrarian cleavage in Spain. The third section offers the baseline results and a replication exercise using instrumental variables. The fourth section examines the two causal channels (one political; the other economic) using g-estimation. The fifth section analyses the transmission mechanism of the family. Finally, the sixth section addresses the external validity of our case with a preliminary exploration of the cases of Italy and England.

\section{Agrarian Conflict}

Analysing the Western party systems of the 1960s, Lipset and Rokkan $(1967,50)$ identified strong continuity with the politics of the interwar period. As they thought that party systems were a reflection of the cleavage structures in society, they conjectured that the apparent continuity was a consequence of the 'freezing' of cleavages after male universal suffrage was introduced in most European countries. The hypothesis was largely confirmed by Bartolini and Mair (1990) in their analysis of voting for ideological blocs during the $1885-1985$ period. ${ }^{1}$

\footnotetext{
${ }^{1}$ During the last three decades, there have been deep technological, economic and social changes that have led to a re-examination of the extent to which the old cleavages have been transformed (for a review, see Ford and Jennings 2020).
} 
Lipset and Rokkan (1967) wrote extensively about the land-industry cleavage. They said little, however, on the agrarian cleavage as such, that is, the social relationships organized around landownership (Urwin [1980] tried to redress this). Compared with industry, property relations in the rural world are complex and varied. Linz (1976) distinguished 13 strata organized in a pyramidal form, with large landowners (latifundium) on top and hired rural labourers at the bottom; in the middle, he identified several situations, from medium and small proprietors to a variety of tenant schemes. We are particularly interested in the most extreme form of conflict: the antagonism between large landowners and landless labourers.

In countries with high levels of agrarian inequality, landowners sought to maintain their privileges and to neutralize the emergence of new industrial elites; consequently, they opposed democracy, which was perceived as a threat to the status quo (Ansell and Samuels 2014; Boix 2003; Moore 1967; Ziblatt 2008). Large landholdings are usually associated with various forms of labour coercion and, therefore, with strongly hierarchical social relations. In response, landless labourers resent their dependence on landowners, particularly if their jobs are only seasonal, and frequently support land redistribution. Politically, therefore, they lean towards the Left. Small farmers, by contrast, tend to be conservative, religious and traditionalist; they do not generally favour land redistribution.

In order to be specific about the kind of persistence we analyse, we rely on cleavage theory. Bartolini and Mair $(1990,215)$ distinguished three elements in a cleavage: (1) the empirical element, defined in socio-structural terms (language, religion, occupation and so on); (2) the normative element, related to the social identities generated by the socio-structural element; and (3) the organizational element, that is, the institutions and organizations (such as parties) that become part of the cleavage. In the case of the agrarian cleavage, the socio-structural element was superseded by industrialization, but the normative and organizational elements survived. ${ }^{2}$ Since the socio-structural element of the agrarian cleavage plays a small role in the contemporary politics of Western countries, we argue that the political dimension of the agrarian cleavage (the normative and organizational elements) can be analysed as a historical legacy of the original socio-structural element regarding landownership.

The agrarian cleavage became particularly salient in the interwar period, when the rural world was politically mobilized for the first time at a mass level. However, its impact varied considerably across Western Europe (Bartolini 2000, 472-5). In countries that industrialized early, agrarian conflict after the First World War was irrelevant or of secondary importance (for example, in Great Britain, Switzerland, Belgium, the Netherlands and Germany). A similar diagnosis holds for countries with more egalitarian land distribution (the Nordic ones), regardless of the timing of industrialization. Things were different in countries with extreme agrarian inequality and late industrialization in the 1920s and 1930s, where landless labourers represented between a third and a half of the working class (in Southern European countries and, to a lesser extent, France). It was in these countries that the agrarian issue was key during the interwar period. Rural conflict polarized politics: leftist formations, particularly socialist parties, were less compromising and more tempted by revolution when agrarian workers had a greater presence in their ranks, in contrast to the reformist socialist or labour parties in early industrializing countries, which had a more homogeneous industrial and urban base (Bartolini 2000, 498-9; Luebbert 1991, 295-302). The agrarian basis of support for leftist parties (socialist, anarchist or communist) in Southern European countries is a well-known phenomenon (Urwin 1980: ch. 4). Moreover, in these countries, the agrarian issue was reinforced by the religious cleavage due to the coalition between large landowners and the Church (Manow 2015). Thus, anti-clerical violence was higher in areas of greater agrarian inequality, whereas in more egalitarian regions, small owners sided with the Church.

\footnotetext{
${ }^{2}$ By the late 1960s, in all Western countries, the industrial sector was bigger than that of the agrarian in terms of labour force (with the exception of Greece and Portugal) (see Bentzen et al. 2013).
} 
Our hypothesis, therefore, establishes that in Western European countries that were industrial laggards and had extreme agrarian inequality (with a strong presence of landless labourers), agrarian conflict was more intense and the many landless poor supported leftist parties, while in areas dominated by small landowners, support for the Right was greater. This association survived industrialization because of two complementary mechanisms that were mentioned in the introduction and are fully explored in the fourth section: an economic one in terms of enduring backwardness; and a political one in terms of persistent political identities that were transmitted generationally.

\section{Historical Background: Agrarian Inequality and Land Conflict in Spain}

In the European context, Spain was a backward country for most of the nineteenth and twentieth centuries. In the 1930s, over 50 per cent of Spain's workforce were still employed in agriculture. In addition, Spain had one of the most unequal distributions of landownership in Western Europe, especially in the south-western quarter of the country. It is true that nineteenth-century land reforms had seen vast tracts of land put up for sale, but land sales did not bring about the emergence of a new class of small- to medium-sized landowners (Bernal 1988, 90-5). Thus, a highly unequal distribution of land inherited from the early modern period persisted into the twentieth century. Comprehensive estimates of landownership inequality at the beginning of the twentieth century do not exist, but by the interwar years, Spain had one the lowest shares of family farms in Western Europe, along with countries like Portugal and Italy (Vanhanen 2003: Appendix 5).

Poverty and dependence on large landowners were pervasive in the most unequal parts of the country, particularly in the southern provinces of Cádiz, Seville and Córdoba. In these provinces, large estates (above 250 hectares) concentrated more than 40 per cent of total land (Carrión 1975). For a long period from the 1880s onwards, rural labourers in Spain turned towards revolutionary ideologies that promised the confiscation and redistribution of land. Anarchist ideologies spread among the landless peasants in the Andalusian provinces of Córdoba, Seville and Cádiz (Díaz del Moral 1973; Kaplan 1977; Maurice 1990).

Given vast inequalities and staggering levels of rural poverty, agrarian conflict became particularly salient during the Second Republic (1931-36) (Domenech 2013; Domenech and Herreros 2017). Anarcho-syndicalist and, especially, socialist unions made big gains in the countryside. The membership of the socialist rural union (the National Federation of Agricultural Workers) went from 36,639 members in 1930 to 451,337 in 1933 (while the total membership of the General Workers' Union was over a million) (Luebbert 1991, 297). The number of strikers in agriculture multiplied twentyfold between 1931 and 1933 (Boletín del Ministerio de Trabajo y Previsión Social, Estadística de Huelgas, 1933/34; Population Census, 1930). Following the electoral victory of June 1931, a parliament dominated by socialists and leftist Republicans passed several rural labour market and tenancy reforms.

In September 1932, the Republican-socialist government introduced an ambitious land reform law (Malefakis 1970, 220-1), which immediately polarized national politics. The interests of small and medium farmers coalesced in 1933 around the Confederación Española de Derechas Autónomas (CEDA), a coalition of minor rightist political parties that included reactionary agrarian parties, Catholic groups and monarchists (Ziblatt 2017, 348-52). Although not generally threatened by land reform, many small- and medium-sized landowners were negatively affected by accompanying reforms in rural labour and land markets, limiting their ability to hire labourers for harvest or their capacity to lease parts of the lands they owned. As a result, small- and medium-sized landowners ended up supporting the reactionary Right in the 1933 election (Luebbert 1991, 297; Manow 2015; Simpson and Carmona 2020, 215-19).

The victory of the Popular Front in the general election of February 1936 accelerated land reform. The government intensified the programme of land expropriations and reinstated government-sanctioned temporary expropriations of land. As in 1932 and 1933, a wave of 
land invasions by local landless peasants swept most municipalities in the south-western region of Extremadura. In July 1936, the Civil War followed a failed coup, dividing the country into two areas controlled by the Republican loyalist and Rebel military forces. In many areas controlled by Republicans, leftist parties, unions and worker militias took control, and land was collectivized (Garrido 1979; Orwell 1962).

The victorious side in the Civil War reversed all previous land expropriations and froze all demands for land redistribution for almost 40 years. Moreover, rapid industrialization in the 1950s and 1960s caused a boom in urban labour demand in the main industrialized areas (the Basque Country, Catalonia and Madrid). As a result, from the mid-1950s, many emigrants left the poorest and most unequal parts of the country. Fast structural change across Spain brought the share of workers in agriculture from 40 per cent in 1960 down to 16 per cent in 1980 (Herrera and Markoff 2012, 458).

Thus, even if rural inequality and poverty persisted in a number of regions, agrarian conflict was pretty much deactivated by the economy's structural change. During the transition to democracy, there were echoes of the conflict, as both landless labourers and small farmers demanded better work conditions and greater protection from the state (Herrera and Markoff 2012; Quirosa-Cheyrouze and Martos 2019). However, the size and frequency of agrarian demonstrations were limited in scope compared with those organized in the industrial and service sectors.

\section{Empirical Analysis}

To test our main hypothesis, we leverage the heterogeneity of the structure of landownership in Spain, testing whether in those territories with historically greater agrarian inequality, support for the Left in the current democratic period is higher. First, we present our data and variables. To minimize the potential effect of measurement error, we use various indicators of agrarian inequality from different periods and measured at the provincial and the municipality levels. Secondly, we provide baseline estimates for contemporary political preferences as a dependent variable and agrarian inequality from the period 1860-1930 as the main explanatory variable. Thirdly, to address potential issues of measurement error and remote confounders, we instrumentalize land inequality with the pattern of the Spanish Reconquest. Fourthly, we introduce contemporary variables that could explain the inclination towards the Left of certain Spanish territories. In this latter case, post-treatment variables are problematic controls as they could both be affecting the outcome and have been affected by past agrarian inequality. In order to avoid potential post-treatment bias, we follow the sequential g-estimation method developed in Vansteelandt (2009) and applied to causal inference in political science (Acharya, Blackwell and Sen 2016b; Charnysh 2015; Homola, Pereira and Tavits 2020).

\section{Data and Variables}

\section{Dependent variable}

Our dependent variable is the electoral support for the main Spanish parties of the Left for the period 1977-2019 (fifteen general elections in total). It should be noted that the party system was not stable throughout this period. For instance, the incumbent party in 1977 and 1979 - the Democratic Centre Union - disappeared after 1982. More importantly, the party system suffered a deep shock after the 2011 elections due to the country's economic and political crisis (three new parties with a vote share of over 10 per cent have emerged since 2015). To avoid these fluctuations, we focus on aggregate support for the Left, including: the Spanish Communist Party (PCE), later on known as the United Left (IU); the Spanish Socialist Worker's Party (PSOE); the Socialist Popular Party (PSP) (it only ran in 1977 and merged with the PSOE in 1979); and since 2015, Podemos and Mas País. We leave aside regionalist and nationalist parties that only compete in a few provinces; although they position themselves on the left-right axis, they are also driven 


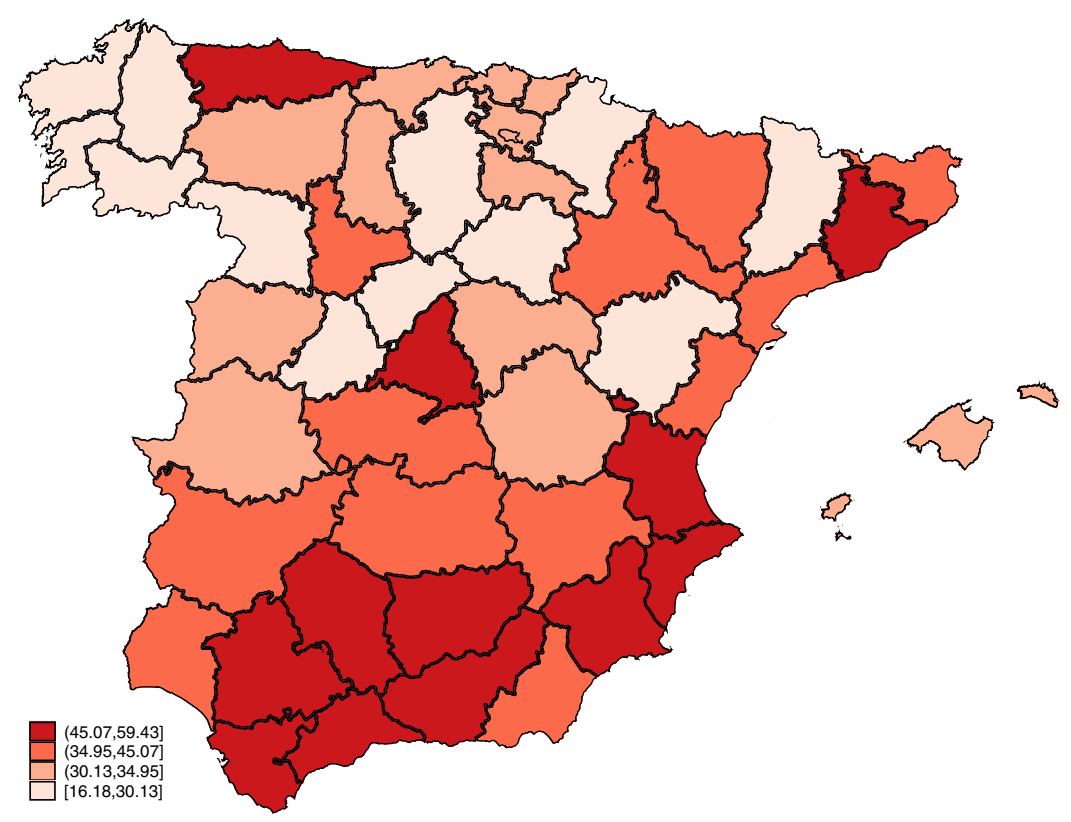

Fig. 1. Electoral support for socialist and communist parties, 1977 general election.

by the centre-periphery cleavage, which falls outside the scope of this article. ${ }^{3}$ Nationalist parties are particularly important in two regions: the Basque Country and Catalonia. To control for this, we include a dummy for these two regions. We report vote share as the percentage of the valid vote. ${ }^{4}$

The distribution of party preferences is geographically concentrated. Figure 1 displays the provincial support for the Left in the first democratic elections in $1977 .^{5}$ The South and the Mediterranean Corridor have darker shades than the Centre and the North-West, indicating greater support for leftist parties.

\section{Agrarian inequality}

The most obvious measurement of agrarian inequality is the distribution of landownership. However, we lack a complete Land Registry for the early twentieth century to be able to assess this. Moreover, the distribution of farm sizes does not adequately capture agrarian inequality. A lot of land on very large estates could not be immediately used for agricultural purposes without large investments. Therefore, purely area-based indicators of inequality can be misleading.

We focus initially on occupational proxies of agrarian inequality by exploiting information on the presence of landless rural labourers in a province using the Population Census of 1860, as in Beltrán and Martínez-Galarraga (2018). Next, we adopt a more granular approach, using municipal-level data and exploiting income-based proxies of agrarian inequality derived from the incomplete Land Registry.

Regarding the 1860 census, we calculate the share of landless farm labourers over the total agricultural population at the provincial level (see Beltrán and Martínez-Galarraga 2018). The assumption is that in those provinces with a greater share of farm labourers, agrarian inequality

\footnotetext{
${ }^{3}$ In footnote 19 , we deal with this issue more extensively.

${ }^{4} \mathrm{We}$ also used vote share as a percentage of the census, and results only change marginally.

${ }^{5}$ In Spain, the electoral district corresponds to the province. Provinces were defined in 1833 and have survived unaltered until today.
} 
was greater. There is a spell of almost 70 years from this measurement to the 1930s, but this is not so problematic once we realize that there were only minor reforms in the period after 1855 . Due to this glacial pace of change, the rank order of the provinces in terms of inequality was not significantly altered between 1860 and $1930 .^{6}$

Secondly, we have used direct income-based proxies of agrarian inequality at the municipal level using information from the Land Registry collected in the 1920s by Pascual Carrión (1975). We use the percentage share of total taxable agricultural income in the municipality corresponding to owners with a taxable income above 5,000 pesetas. ${ }^{7}$ This covers most municipalities in the provinces for which Carrión collected the data (Badajoz, Ciudad Real, Cáceres, Cádiz, Córdoba, Jaén, Málaga, Salamanca and Seville). This exercise gives a municipal-level dataset with income-based estimates of agrarian inequality in 882 municipalities. Our results at the municipal level should eliminate concerns about a problem of over-aggregation in the provincial analysis.

\section{Geographical controls}

Both in the provincial and municipal analyses, we add latitude and longitude to control for hidden spatial patterns. We also control for the altitude of the province capital in the provincial analysis and the altitude of the municipality in the municipal analysis.

\section{Contemporary variables}

We control for various contemporary province characteristics measured at each election year: the rate of unemployment, level of education and percentages of workers in the agricultural and industrial sectors. Table A1 in the Online Appendix contains descriptive statistics for the variables.

We start by analysing the impact of past agrarian inequality on leftist political preferences. In Table 1, we report the baseline estimates of the effects of agrarian inequality on leftist vote for the 1977-2019 period (fifteen general elections). Column 1 displays the baseline models regressing the percentage leftist vote against 1860 inequality, the geographical controls, the dummy for historical regions and election year dummies. Column 2 presents the municipal-level analysis in the nine aforementioned provinces. Column 3 corresponds to a probit model in which vote intention for the 1977 elections at the individual level is regressed against agrarian inequality in 1860 plus a battery of socio-demographic controls.

The coefficient in column 1 shows a positive and significant effect of historical land inequality on contemporary voting patterns across the general elections. An increase in ten percentage points in the share of landless peasants produces an increase of four percentage points in the leftist vote. Table B1 in the Online Appendix reports results by election with the measures of both 1860 and 1920: the coefficient is significant in each election, the strongest effect being registered

\footnotetext{
${ }^{6}$ As a robustness check, we try an alternative proxy for land inequality based on the 1920 Population Census, using the counts by sector and occupation in each province. The 1920 Population Census divided peasants between 'patronos' (could be similar to owners, definitely not workers) and 'No patronos' (workers). It is unclear how a small owner working his own land is categorized; given this ambiguity, we use this census only as a robustness check. We calculate the percentage of workers who are not 'patronos' (owners) in the agricultural sector at the provincial level. We assume that the higher the percentage of non-owners to owners in the agricultural sector, the greater the agrarian inequality. The correlation between the 1920 ratio and the 1860 percentage of landless labourers is 0.45 . The main discrepancy between the two measures is located in the three Basque provinces. If they are removed, the correlation increases to 0.51 . For these reasons, we only report regressions using the 1920 proxy as extra robustness checks in the Online Appendix.

${ }^{7}$ In Carrión (1975), the denominator is total agricultural income measured as the yearly value of all agricultural and related activities according to the Land Registry. The latter figure includes rental payments on the land used, interest payments on capital used and profits (Carrión 1975, 97). Carrión considered the largest landowners had an estimated income above 5,000 pesetas; this represented about 1 per cent of all owners across Spain and about 2 per cent of all owners in the typically unequal provinces of Andalusia (Carrión 1975, 109).
} 
Table 1. Effects of historical agrarian inequality on contemporary voting for the Left

\begin{tabular}{|c|c|c|c|}
\hline & $\begin{array}{c}1 \\
\text { Leftist vote }\end{array}$ & $\begin{array}{c}2 \\
\text { Leftist vote }\end{array}$ & $\begin{array}{c}3 \\
\text { Vote intention } \\
\text { Marginal effect } \\
\text { df/dx }\end{array}$ \\
\hline$\%$ landless, 1860 & $\begin{array}{l}0.406^{\star \star \star} \\
(0.086)\end{array}$ & & $\begin{array}{l}0.006^{\star \star \star} \\
(0.002)\end{array}$ \\
\hline$\%$ income largest landowners, 1920 s & & $\begin{array}{l}0.082^{\star \star \star} \\
(0.017)\end{array}$ & \\
\hline Level & Provincial & Municipal & Individual \\
\hline Provincial controls & $\checkmark$ & & $\checkmark$ \\
\hline Municipal longitude, latitude, altitude & & $\checkmark$ & \\
\hline Gender, age, education, religion & & & $\checkmark$ \\
\hline Elections & $1977-2019$ & $1977-2019$ & 1977 \\
\hline Election year fixed effects & $\checkmark$ & $\checkmark$ & \\
\hline Std errors clustered by: & Province $(50)$ & Municipality (885) & Province $(50)$ \\
\hline Model & Pooled OLS & Pooled OLS & Probit \\
\hline $\mathrm{N}$ & 750 & 7,695 & 8,947 \\
\hline $\mathrm{R}^{2}$ & 0.45 & 0.38 & \\
\hline
\end{tabular}

Notes: Provincial controls: latitude, longitude, average altitude and dummy for historical region. Municipalities from Córdoba, Jaén, Málaga, Sevilla, Cádiz, Badajoz, Cáceres, Salamanca and Ciudad Real. ${ }^{\star} p<0.1 ;{ }^{\star \star} p<0.05 ;{ }^{\star \star \star} p<0.01$.

in 1982; the effect becomes weaker, as might be expected, after the breakdown of the party system in the post-2011 elections. ${ }^{8}$

Column 2 uses the municipal dataset with 513 municipalities in nine provinces in the fifteen general elections. We exclude municipalities with fewer than 1,000 voters to avoid the spurious volatility of the vote share in small municipalities. ${ }^{9}$ The main explanatory variable is the proxy for income inequality from the Land Registry (see earlier). As these provinces had generally high levels of agrarian inequality, this is a demanding test of the main hypothesis. Nonetheless, the effect of inequality on voting almost half a century later gives a highly significant point estimate of 0.082 , meaning that a one standard deviation increase in inequality increases the leftist vote by two percentage points, which is 15 per cent of the standard deviation in the leftist vote. This regression includes geographical controls, and the effect is robust to the inclusion of province fixed effects.

Since there are potential concerns with ecological analyses, we have also carried out an analysis ${ }^{10}$ with individual data. Column 3 displays the results of a survey conducted in 1977 (survey 1135 by the Centro de Investigaciones Sociológicas). Respondents were asked about their voting preferences before the first elections of the democratic period, when there was still much uncertainty about the levels of support for the various parties. The dependent variable is a dichotomous one, where 1 corresponds to preferences for left-wing parties and 0 for right-wing formations. People who do not report voting preferences or are willing to vote for minor parties are excluded from the analysis. The independent variable is the provincial percentage of landless labourers in 1860. At the individual level, we control for gender, age, education and religion; at the provincial level, we control for latitude, longitude and altitude, as well as for historic regions. We estimate a probit model (clustering standard errors by province). The working sample is close to 9,000 respondents. The coefficient of agrarian inequality is positive and highly significant. Keeping

\footnotetext{
${ }^{8}$ In addition, we perform extra robustness checks using the flawed 1920 measurements of agrarian inequality. These regressions are in columns 1 and 2 of Table $\mathrm{C} 1$ in the Online Appendix. The coefficient stays positive and statistically significant. Also, we have re-estimated our results including left-wing nationalist parties but the results hold (see Table L1 in the Online Appendix).

${ }^{9}$ We provide the same regression with the complete database with 882 municipalities in Table G1 in the Online Appendix.

${ }^{10}$ Data can be found in http://www.cis.es/cis/opencm/EN/2_bancodatos/estudios/ver.jsp?\&cuestionario=137\&estudio=127\& muestra $=2701$.
} 
the other variables at their means, the probability of voting for the Left in 1977 with 30 per cent of provincial landless labourers in 1860 is 35.1 per cent; with 70 per cent of landless labourers, it goes to 59.6 per cent. The marginal effect reported in Table 1 is 0.006 . Overall, baseline results point to an important and robust effect of agrarian inequality in contemporary patterns of voting.

\section{Instrumenting Agrarian Inequality with Speed of Reconquest}

Historical census data can contain significant levels of measurement error, especially in the recording of occupations. For this reason, it might be the case that the coefficients from our baseline regressions are attenuated towards zero. We follow Oto-Peralías and Romero-Ávila (2016), Beltrán and Martínez-Galarraga (2018) and Tur-Prats (2019), who have used Spain's Reconquest as an instrument for agrarian inequality and coercive institutions. The Reconquest is the period spanning from the ninth century to the fall of the kingdom of Granada in 1492, in which Christian kingdoms in the north of Spain fought Muslim kingdoms that had been present in the peninsula since the early eighth century. This period had different stages, and the speed and characteristics of this process have been linked to different settlement patterns, institutions and land holdings. The initial period of the Reconquest was characterized by a relatively compact settlement, leading to egalitarian political institutions, free peasants and dispersed landownership. In contrast, after Toledo fell into Christian hands in 1085, the aristocracy and the so-called 'military orders' were in charge of guaranteeing the protection of settlers in contested terrain south of the Tagus River. The result was a very dispersed pattern of settlement, with populations of dependent, landless peasants concentrated in large towns. Landownership inequality was greater in these parts of the peninsula, and has remained so until the present day. On the basis of this historical narrative, we use the 'speed of the Reconquest' as an instrument for mismeasured agrarian inequality in $1860 .^{11}$

Feudal privilege is linked to other factors, like lower levels of social capital and education, which might also be correlated with contemporary political outcomes (Baten and Hippe 2018; Baten and Juif 2014), violating the exclusion restriction. We therefore add to our specification the rate of illiteracy in 1860 as an extra control blocking potential impacts of feudal privilege on political preferences other than inequality. By including illiteracy, the levels of human and social capital are taken into account, and the instrument captures agrarian inequality. Table 2 displays the results from the two-stage least squares regressions using 'speed of Reconquest' as an instrument for 1860 inequality.

Regressions in Table 2 confirm the baseline results. ${ }^{12}$ The two-stage least squares (2SLS) coefficient for agrarian inequality is positive and large. ${ }^{13}$ We have replicated this regression for each election in Table D1, getting in every case positive, large coefficients for the variable 'speed of Reconquest'. ${ }^{14}$

\footnotetext{
${ }^{11}$ We thank Daniel Oto-Peralías for providing his estimates of Reconquest speed.

${ }^{12}$ As in Beltrán and Martínez-Galarraga (2018), in the first stage (column 1), there is a positive relationship between agrarian inequality in 1860 and illiteracy rates in the same year. In the second stage regression, illiteracy commands a negative coefficient; it might be the case that once we control for levels of agrarian inequality, illiteracy is negatively correlated with political mobilization via negative effects on social capital.

${ }^{13}$ Results using the less reliable proxy of inequality in 1920 can be found in columns 3 and 4 in Table $\mathrm{C} 1$ in the Online Appendix. Also, we have re-estimated results including left-wing nationalist parties (see Table L1 in the Online Appendix).

${ }^{14}$ Results for each election year using the proxy of 1920 inequality are in column 2 of Table D1 in the Online Appendix. Also in the Online Appendix, because the speed of Reconquest was connected with a dispersed pattern of settlement (Oto-Peralías 2020), we have used the average area of municipalities in each province in 1860 to instrument for land inequality in 1860 and in 1920. Table E1 in the Online Appendix displays the coefficients of 2SLS regressions similar to the ones presented in Table 2 using average municipal area in the province as an instrument for land inequality. Table E2 displays the relevant coefficients of an alternative regression using both instruments to predict land inequality.
} 
Table 2. Instrumental variable estimates of effect of agrarian inequality on the leftist vote (elections 1977-2019)

\begin{tabular}{|c|c|c|c|}
\hline & 1 & 2 & 3 \\
\hline & Leftist vote reduced form & $\begin{array}{l}1860 \text { percentage } \\
\text { landless IV, first stage }\end{array}$ & $\begin{array}{l}\text { Leftist vote IV, } \\
\text { second stage }\end{array}$ \\
\hline Speed of reconquest & $\begin{array}{l}0.694^{\star \star \star} \\
(0.189)\end{array}$ & $\begin{array}{l}0.912^{\star \star \star} \\
(0.047)\end{array}$ & \\
\hline Illiteracy, 1860 & $\begin{array}{l}-0.061 \\
(0.072)\end{array}$ & $\begin{array}{l}0.101^{\star \star \star} \\
(0.039)\end{array}$ & $\begin{array}{l}-0.138^{\star \star \star} \\
(0.037)\end{array}$ \\
\hline$\%$ landless, 1860 & & & $\begin{array}{l}0.762^{\star \star \star} \\
(0.069)\end{array}$ \\
\hline Level & Province & Province & Province \\
\hline Provincial controls & $\checkmark$ & $\checkmark$ & $\checkmark$ \\
\hline Model & OLS & $2 S L S$ & \\
\hline N & 750 & 750 & 750 \\
\hline F stat first stage & & $\begin{array}{l}53.41^{\star \star \star} \\
d f(20,729)\end{array}$ & \\
\hline
\end{tabular}

Notes: Provincial controls: latitude, longitude and capital altitude. Robust standard errors in parentheses. ${ }^{*} p<0.1 ;{ }^{* \star} p<0.05 ;{ }^{* \star \star} p<0.01$.

\section{Channels}

According to our argument, agrarian inequality affects contemporary political preferences through two channels. The first causal pathway links agrarian inequality to contemporary political preferences through the political turmoil of the 1930s. We have selected as mediators two highly consequential events that capture the political dynamics of the period. First, we select support for the Popular Front in the 1936 February elections (it included all the centre-left and leftist parties in a joint coalition that won the elections). These were the Second Republic's most polarized elections, in which the electorate split into two opposing ideological sides. The agrarian question played an important role, and this cleavage was reinforced by the state-Church and the centre-periphery divisions. Five months later, the military coup against the Republic failed and brought about the Civil War. Our second mediator is Civil War repression, which deepened the political divisions between the ideological blocs and left painful scars on society. Despite the unfavourable conditions of the long dictatorial spell, we surmise that the political identities forged during the late 1930s persisted for generations to come.

The second channel is economic: agrarian inequality had long-term consequences like delayed industrialization, low human capital, poverty and unemployment (Oto-Peralías and Romero-Ávila 2016); and under these conditions, the distributional issue became more acute and fostered stronger preferences for the Left among the poor.

In order to separate these two channels and to correct for potential post-treatment bias, we employ techniques from the literature on mediation analysis. In the model, historical agrarian inequality has both an effect on the mediators (voting in the 1936 elections and Civil War violence) and on the intermediate confounders (the contemporary economic conditions of the provinces). The existence of intermediate confounders and post-treatment bias suggests that a causal mediation model should be adopted. In this sense, we follow Acharya, Blackwell and Sen (2016a) and use sequential g-estimation to isolate the two potential causal relationships.

Our first step is a directed acyclic graph (DAG) displaying the main causal relationships in our simple model (see Figure 2). The graph specifies the pre-treatment variables (geographical factors and old regime characteristics), the treatment (historical agrarian inequality), the mediator variables in the political channel (the 1936 elections and Civil War repression) and the post-treatment variables that are contemporaneous to the outcome variable (levels of industrialization, education and unemployment at the time of the elections during 1977-2019).

To proceed with the sequential g-estimation, we first expand our baseline regressions to include the mediator variables and the intermediate confounders alternatively. One first snapshot 


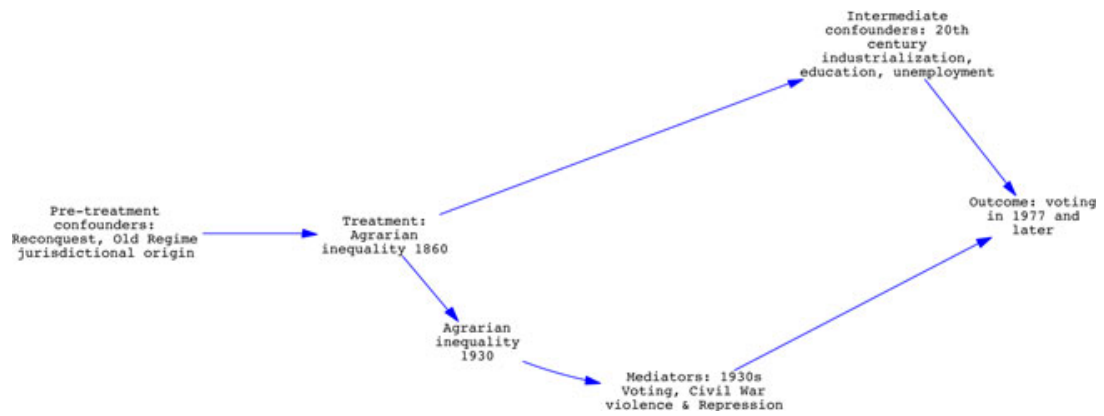

Fig. 2. DAG explaining political attitudes in the democratic period in Spain.

of the relative importance of these channels can be simply grasped by gauging the change in the main coefficient on agrarian inequality when adding the mediators or the intermediate confounders to the baseline specification (Baron and Kenny 1986). For the mediators, we use the provincial percentage of the vote going to the Popular Front in the general election of February 1936 (the source is Alvarez Tardío and Villa [2017]). Regarding Civil War repression, we use the data from Espinosa (2010). ${ }^{15}$ For the analysis, we include only the number of civilians killed by the Rebels since the repression of the Republicans is associated with support for the Popular Front in the 1936 elections (it makes little sense to assume that Republican repression strengthens leftist allegiances). We 'normalize' the number of murdered civilians using the inverse hyperbolic sine function. ${ }^{16}$

We start by analysing the main channels using the provincial-level data in Table 3. Column 1 uses the same variables as in Table 1 but now adds the percentage vote going to the Popular Front in 1936, as well as rightist Civil War repression. The two variables have positive and large coefficients. Adding the mediators sharply reduces the baseline coefficient of 1860 agrarian inequality from 0.406 to 0.107 . In column 3 , we focus on the intermediate confounders. Contemporary unemployment gets a large, significant coefficient while the other confounders are nonsignificant. The coefficient on 1860 inequality (0.294) is three times as big as that of column 1 , showing a smaller reduction through this channel. Although these estimations are affected by post-treatment bias, they suggest that the political mechanism is a more dominant channel than the intermediate economic confounders.

Moving to the sequential g-estimate, we have applied the Stata code from Acharya, Blackwell and Sen (2016a) to estimate the controlled direct effects of the treatment variable. This procedure de-means the main variable to keep the intermediate confounders or the mediator constant, re-estimates the regression without post-treatment variables and bootstraps the standard errors of the coefficient of interest. In column 4, we present the results of the sequential g-estimation when the intermediate confounders (unemployment, education and industrialization) are fixed. The coefficient on agrarian inequality in 1860 captures the effect that goes through the political channel, in this case, the front-door pathway via our selected mediators. We obtain a very similar coefficient of land inequality to that of column 3. A one standard deviation increase in 1860 inequality (10.24 percentage points) is associated with a 2.94 percentage point increase in the leftist vote, which represents almost a third of the standard deviation in the leftist vote. ${ }^{17}$

\footnotetext{
${ }^{15}$ We are thankful to Francisco Espinosa, who provided us with updated provincial figures of repression.

${ }^{16} \mathrm{We}$ use this function instead of the log because there are zeroes in the repression data.

${ }^{17}$ Although we consider that both the effect of the Popular Front and the effect of Civil War repression are conceptually part of the same effect related to 1930s' political mobilization, we might wonder which of the two mediators has a more powerful effect on the leftist vote. In Table H1 in the Online Appendix, we provide the separated effects. The effect through
} 
Table 3. Provincial mediator analysis: Popular Front channel augmented with Civil War violence

\begin{tabular}{|c|c|c|c|c|}
\hline & Leftist vote & $\begin{array}{c}2 \\
\text { Leftist vote } \\
\text { Sequential g-estimate } \\
\text { Channel: poverty }\end{array}$ & Leftist vote & $\begin{array}{c}4 \\
\text { Leftist vote } \\
\text { Sequential g-estimate } \\
\text { Channel: Popular } \\
\text { Front + Civil War }\end{array}$ \\
\hline$\%$ landless, 1860 & 0.107 & $0.105^{\star \star \star}$ & $0.294^{\star \star \star}$ & $0.287^{\star \star \star}$ \\
\hline $\begin{array}{l}\text { (Baseline: } 0.406^{\star \star \star} \text { ) } \\
\text { Mediators }\end{array}$ & $(0.067)$ & $(0.04)$ & $(0.077)$ & $(0.041)$ \\
\hline$\%$ vote Popular Front, 1936 & $\begin{array}{l}0.19^{\star \star \star} \\
(0.056)\end{array}$ & & & \\
\hline Rightist repression, Civil War & $\begin{array}{l}4.054^{\star \star \star} \\
(0.824)\end{array}$ & & & \\
\hline Intermediate confounders & & & & \\
\hline Unemployment rate, \% & & & $\begin{array}{l}0.613^{\star \star \star} \\
(0.14)\end{array}$ & \\
\hline$\%$ employed in industry & & & $\begin{array}{l}0.124 \\
(0.098)\end{array}$ & \\
\hline Education & & & $\begin{array}{l}0.204 \\
(1.165)\end{array}$ & \\
\hline Level & Province & Province & Province & Province \\
\hline Controls province & $\checkmark$ & $\checkmark$ & $\checkmark$ & $\checkmark$ \\
\hline Elections & 1977-2019 & 1977-2019 & 1977-2019 & $1977-2019$ \\
\hline Election-year fixed effects & $\checkmark$ & $\checkmark$ & $\checkmark$ & $\checkmark$ \\
\hline Model & Pooled OLS & Sequential g-estimate & Pooled OLS & Sequential g-estimate \\
\hline Clustered Standard Errors & Province & & Province & \\
\hline Bootstrapped Standard Errors & & $\checkmark$ & & $\checkmark$ \\
\hline $\mathrm{N}$ & 750 & 750 & 750 & 750 \\
\hline $\mathrm{R}^{2}$ & 0.58 & & 0.52 & \\
\hline
\end{tabular}

Notes: Provincial controls: latitude, longitude and average altitude. ${ }^{*} p<0.1 ;{ }^{* \star} p<0.05 ;{ }^{\star \star \star} p<0.001$.

Column 2 looks at the other potential channel, this time de-meaning the level of the mediators (Popular Front and rightist repression in the Civil War) with the same procedure. The coefficient hardly changes with regard to that in column 1 , confirming that both channels matter ${ }^{18}$ but the political channel far more so. ${ }^{19}$

We now replicate these results using municipal data. In this case, it was impossible to replicate the analysis for the municipalities from the nine provinces in Table 1, as there is no comprehensive municipal-level data set of electoral results in 1930s' Spain. We analyse the 112 municipalities of Badajoz and Cáceres (both forming the Extremadura region), with more than 1,000 voters. Electoral data have been compiled by Espinosa (2007) and Ayala (2001). We provide the same analysis for the whole set of 222 municipalities in Extremadura, with complete information in Table G1 in the Online Appendix. Since the intermediate confounders used in the provincial analysis are not available for municipalities, we use two alternative variables. We proxy the level of

the Popular Front mediator is smaller than the effect of Civil War repression, but they are more or less of equal size and larger than the 'economic' effect via the intermediate confounders.

${ }^{18}$ Further confirmation is obtained when we address in a more detailed way the spatial auto-correlation of our geographical data. In Tables J1 and J2 in the Online Appendix, we present replications of the baseline provincial regressions and the mediation analysis, allowing for spatial auto-correlation of errors and using spatially lagged dependent variables. The coefficients are roughly similar to those of the baseline regressions and the mediation analysis in columns 2 and 3 of Table 3 . Similar results with data from 1920 can be found in Table F1 in the Online Appendix. These results suggest that the Popular Front mediator dominates over the intermediate confounders.

${ }^{19}$ The introduction of the vote for leftist nationalist or regionalist parties does not alter the global results, but in the political channel, the Civil War mediator gains relevance vis-a-vis the Popular Front (see Table L2 in the Online Appendix). This is not so surprising given that repression affected all leftist parties, whether nationalist or not, whereas the vote for the Popular Front in 1936 was mainly driven by left-right ideology. 
education using the illiteracy rate of 1930 (assuming that the ranking order between municipalities does not change significantly), we control for development by adding population change in the municipality between 1930 and 1970 (assuming that faster population growth is associated with development), and we use the total number of voters in each municipality in each election as a proxy for contemporary population.

Municipal results appear in Table 4. Column 1 includes the mediators (Popular Front vote and rightist Civil War repression). When the mediators are included, the coefficient of the treatment variable falls to 0.059 (from the 0.081 baseline) ${ }^{20}$ Column 3 presents the regression excluding the mediator but including the intermediate confounders. The effect of agrarian inequality is now 0.079 , which is much closer to the baseline coefficient. The results of the g-estimation in columns 2 and 4 confirm these results. ${ }^{21}$ Although there is a risk of omitted variable bias, these preliminary results suggest that the effect of historical agrarian inequality on contemporary voting patterns flows with greater intensity through political preferences in the 1930s.

In Tables I1 and I2 in the Online Appendix, we replicate the previous analyses adding the pre-treatment confounders specified in Figure 2. We use the Instituto Nacional de Estadística (INE 1986) to add pre-treatment variables: the share of landless peasants in the population in 1787 as a proxy for agrarian inequality; and dummies capturing the type of feudal jurisdiction of the municipality (municipality under the king's jurisdiction or under the jurisdiction of the nobility, the Church and the so-called military orders, with the reference category being the municipalities under the king's jurisdiction, in Spanish, realengo municipalities). As it is difficult to construct aggregate measures of pre-treatment confounders at the provincial level, we add the 'speed of Reconquest' as an extra regressor. The coefficients on our proxy for agrarian inequality in columns 2 and 4 of Tables I1 and I 2 in the Online Appendix reinforce the results in Tables 3 and 4: the 'political' mediators have a stronger effect than the 'economic' intermediate confounders.

\section{Political Allegiances}

We interpret the results on the political channel as evidence that the agrarian conflict culminating in the interwar period forged resilient political identities that survived Franco's long dictatorship (1939-77). This interpretation is consistent with Maravall (1982), who highlighted the remarkably close spatial correlation between the last elections of the Second Republic in 1936 and the first democratic elections after Franco's death in 1977.

The question that remains to be answered is how ideological allegiances have survived for such a long period of time under such unfavourable historical circumstances. The literature on historical legacies has contemplated several transmission mechanisms: the Church (Wittenberg 2006), the school (Darden and Grzymala-Busse 2006) and the family (Acharya, Blackwell and Sen 2016b; Lupu and Peisakhin 2017; Voigtländer and Voth 2012).

Taking into account the peculiar history of Spain during the twentieth century, we surmise that the main transmission channel of political identities, particularly for those on the Left, was the family. This seems an inescapable conclusion given the extraordinary length of Franco's regime. Over almost four decades, parties and unions were banned. The Church, moreover, was closely aligned with the dictatorship. ${ }^{22}$ Education was under the control of the state and

\footnotetext{
${ }^{20}$ The baseline coefficient in Table 1 is 0.082 ; replicating the same analysis for the municipalities in the two provinces of Extremadura gives a baseline coefficient of 0.081 .

${ }^{21}$ Although we prefer to consider the Popular Front mediator and the Civil War repression mediator as part of the same mediator associated with 1930s' political mobilization, in Table H2 in the Online Appendix, we separate both effects. In this case, the Popular Front channel is stronger than the repression channel. Both mediators have stronger effects than the intermediate confounders.

${ }^{22} \mathrm{~A}$ faction of the Church changed after the Second Vatican Council and supported workers' demands. The main clandestine union, Comisiones Obreras (Workers' Councils), which was close to the Communist Party, had Catholic roots. However, these late changes cannot account for the persistence of leftist identities during the first half of Francoism.
} 
Table 4. Municipal mediator analysis, popular front channel augmented with Civil War violence

\begin{tabular}{|c|c|c|c|c|}
\hline & $\begin{array}{l}1 \\
\text { Leftist vote }\end{array}$ & $\begin{array}{c}2 \\
\text { Leftist vote } \\
\text { Sequential g-estimate. } \\
\text { Channel: poverty }\end{array}$ & Leftist vote & $\begin{array}{c}4 \\
\text { Leftist vote } \\
\text { Sequential g-estimate. } \\
\text { Channel: Popular Front + Civil War }\end{array}$ \\
\hline Largest landowners & $0.059^{\star \star}$ & $0.037^{\star \star \star}$ & $0.079^{\star \star}$ & $0.079^{\star \star \star}$ \\
\hline $\begin{array}{l}\% \text { income, } 1920 \mathrm{~s} \\
\left(\text { Baseline }=0.081^{\star \star \star}\right)\end{array}$ & $(0.027)$ & $(0.013)$ & $(0.029)$ & $(0.013)$ \\
\hline \multicolumn{5}{|l|}{ Mediators } \\
\hline$\%$ vote Popular front, 1936 & $\begin{array}{l}0.252^{\star \star \star} \\
(0.051)\end{array}$ & & & \\
\hline Rightist repression & $\begin{array}{l}1.145^{\star} \\
(0.668)\end{array}$ & & & \\
\hline \multicolumn{5}{|l|}{ Intermediate confounders } \\
\hline Illiteracy rate, 1930 & & & $\begin{array}{l}0.232^{\star \star \star} \\
(0.103)\end{array}$ & \\
\hline Population growth, 1930-70 & & & $\begin{array}{l}-0.005 \\
(0.006)\end{array}$ & \\
\hline Number of voters & & & $\begin{array}{l}-0.0002^{\star \star \star} \\
(0.00004)\end{array}$ & \\
\hline Level & Municipal & Municipal & Municipal & Municipal \\
\hline Municipalities from provinces & 1,2 & 1,2 & 1,2 & 1,2 \\
\hline Municipal controls & $\checkmark$ & & $\checkmark$ & \\
\hline Election & 1977-2019 & $1977-2019$ & $1977-2019$ & $1977-2019$ \\
\hline Model & OLS & Seq g-est & OLS & Seq g-est \\
\hline Clustered Standard Errors & municipality & municipality & municipality & municipality \\
\hline Bootstrapped Standard Errors & & $\checkmark$ & & $\checkmark$ \\
\hline $\mathrm{N}$ & 1,668 & 1,668 & 1,668 & 1,668 \\
\hline $\mathrm{R}^{2}$ & 0.53 & & 0.46 & \\
\hline
\end{tabular}

Notes: Controls: altitude, latitude and longitude. Provinces: Badajoz (1) and Cáceres (2). ${ }^{\star} p<0.1 ;{ }^{\star \star} p<0.05 ;{ }^{\star \star \star} p<0.001$. 
the Church. The Church and the school may have contributed to the reinforcement of rightist identities, but not to leftist ones. Ruling out the Church, school, parties and unions, we are left to conclude that the most likely agent of generational transmission was the family (for a similar argument, see Tilley 2015). The importance of the family for transmission of political values is a well-documented finding in the literature on political behaviour (see, among many others, Jennings 1984; Jennings, Stoker and Bowers 2009; Ventura 2001).

In the absence of panel data, we cannot prove family transmission. However, we leverage $a^{23}$ unique survey that provides evidence for it (survey 2760 [April 2008] of the Centro de Investigaciones Sociológicas). It contains information about the respondents' ideology and the ideology that they attribute to their parents, as well as the side their ancestors took during the Civil War. If the transmission of ideology goes through the family, we should observe that respondents living in provinces with higher pre-1936 agrarian inequality attribute more leftist positions to their parents. If this is confirmed, the case for family transmission is substantially reinforced.

The ideological scale goes from 1 (extreme left) to 10 (extreme right). The correlation between the respondent's ideology and the ideological position attributed to their mother and father is 0.60 and 0.56 , respectively. Moreover, the association between the parents' ideology and the side that the family took during the Civil War is very strong. For instance, when the family supported the military Rebels, the ideology attributed to the father is 6.94, compared with only 4.37 in other cases (a Republican family or a divided one). The difference is strongly significant and tends to confirm the cross-generational transmission of ideological values. More systematic means comparisons are presented in Table M1 in the Online Appendix.

Going beyond bivariate relationships, we conduct an ordinary least squares (OLS) regression with province-clustered standard errors in which the dependent variable is the ideology attributed to the parents (the average of the mother's and father's positions). We also control for other individual traits that might have an effect on the respondent's ideology: gender, age, education and religiosity. As for provincial variables, we introduce the percentage of landless labourers in 1860, as well as the unemployment rate and the percentage of workers in the industrial sector in 2008. Full results are reported in the in Table N1 in the Online Appendix. Here, we only focus on the provincial coefficients.

Figure 3 displays two coefficient plots. In the left panel, the coefficient on agrarian inequality is negative and significant at a 90 per cent confidence level (the higher the level of agrarian inequality, the more leftist the ideology attributed to the parents). An increase of ten points in the percentage of landless labourers in 1860 implies a shift of 0.22 points towards the left in the ideology attributed to the parents. Contemporary levels of unemployment and industrialization are negative and significant. The higher the level of unemployment, the more leftist the parents' ideology. Also, in more industrialized provinces, the parents are more leftist.

In the right panel, two dummies for the sympathy of the family during the Civil War with the two sides (the Republic and the military rebels) have been added. The reference category is those who do not answer or say that their family had no sympathy for either side, or that the family was divided. In line with the results about the causal channel of the previous section, we expect that once we control for the family's political allegiances in the 1930s, the effect of agrarian inequality is weakened. This is precisely what we observe: whereas the coefficients of unemployment and industry are still significant (although less so), the coefficient of agrarian inequality is cut by more than half and loses significance.

The analysis of the survey supports our main argument and adds plausibility to the family transmission mechanism. In provinces with higher historical agrarian inequality, respondents place their parents on more leftist ideological positions. The effect, however, is neutralized

\footnotetext{
${ }^{23}$ Data can be found in http://www.cis.es/cis/opencm/EN/2_bancodatos/estudios/ver.jsp?\&cuestionario=10774\&estudio= 9220\&muestra $=16345$.
} 


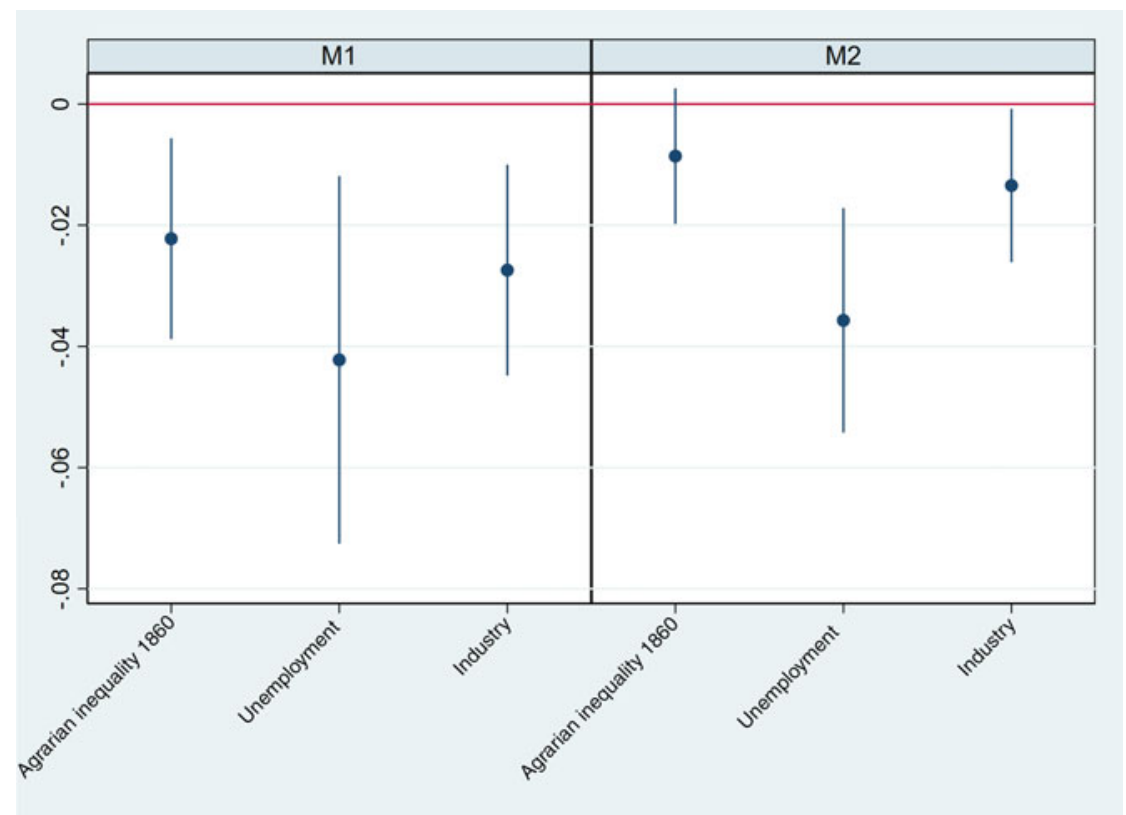

Fig. 3. Coefficient plot: M1 without family's sympathies during the Civil War; M2 with family's sympathy during the Civil War.

when we control for the family's political sympathy during the Civil War, which is consistent with the political channel.

\section{Comparative Discussion}

We now discuss if agrarian legacies can be found in other European democracies. Following Bartolini (2000), the scope conditions of our hypothesis on the electoral effects of the agrarian conflict are twofold: late industrialization and high agrarian inequality when mass politics arrived in the interwar years. Spain meets these conditions and the hypothesis is confirmed. In this section, we provide exploratory evidence of two other cases: Italy and England. ${ }^{24}$ Both had agrarian inequality, but Italy is a late industrializer and England an early one. Therefore, we expect to find in Italy the same pattern as in Spain: greater support for the Left in regions with historically large rural inequality. In England, however, we should not find a positive association, as the agrarian question was already in the past when mass politics emerged in the interwar period.

In the case of Italy, we combine voting patterns in the 1976 elections with evidence on agrarian inequality from the 1930s. By 1930, 52 per cent of Italy's gainfully employed were employed in agriculture (Broadberry, Giordano and Zollino 2011). We use the Population Census of 1931 to calculate the proportion of landless peasants in the population. The unit of analysis is the electoral district. In Figure 4, the vertical axis separately represents the proportion of votes cast in favour of the Italian Communist Party and of all leftist parties together (including the Communist Party) in the 1976 general elections. These were the elections in which support for the Communist Party peaked in the Italian First Republic. Given very fast structural change

\footnotetext{
${ }^{24}$ An analysis for the whole of the UK or for Great Britain could not be performed for lack of 1830s' data, so we restrict our analysis to England only.
} 


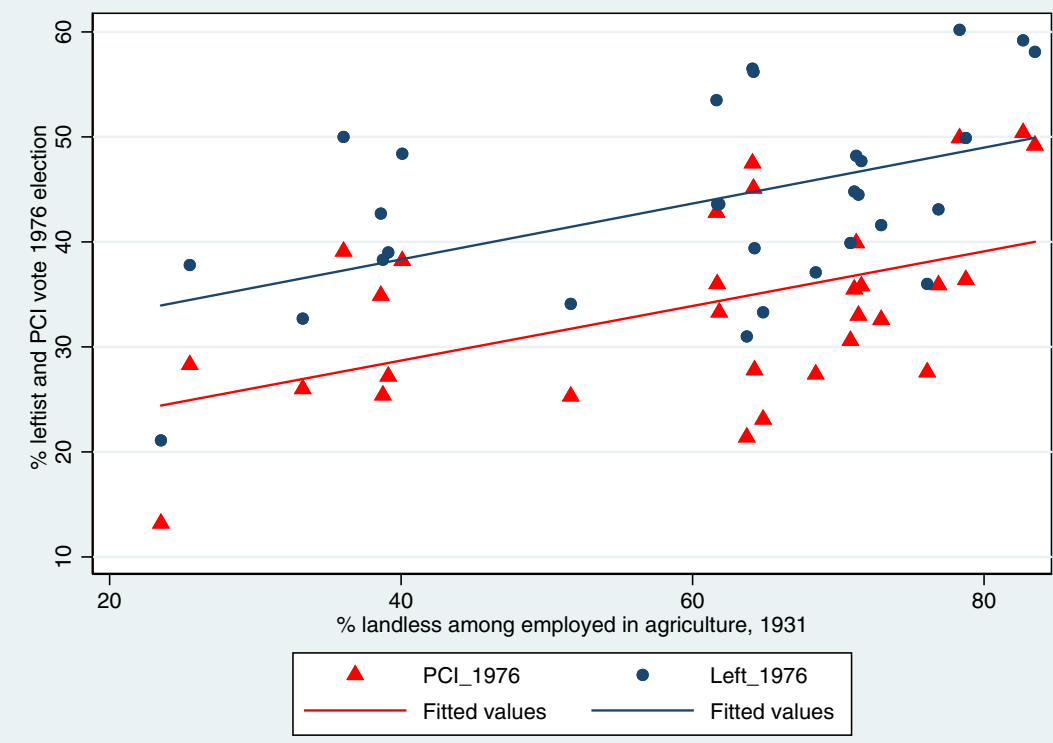

Fig. 4. Relationship between agrarian inequality and leftist vote in Italy. Note: $\mathrm{PCl}=$ Italian Communist Party.

in the 1950s and 1960s, agrarian issues were not a central concern of voters in the 1970s. However, in the case of the elections studied here, a pretty tight and a positive gradient linking agrarian inequality and preferences for leftist political parties is visible in the data. A purely exploratory analysis generates positive, significant coefficients and high goodness of fit. We use the Italian case for illustrative purposes, and do not elaborate on the complex political story behind it. Figure 4 is consistent with the main hypothesis of the article. In the Online Appendix (see Figure O1), we discuss the case of Portugal, which also shows a positive correlation between historical agrarian inequality and contemporary support for leftist parties.

The Italian case contrasts sharply with the geographical distribution of leftist preferences in England. In this case, we combine electoral support for the Labour Party in the five elections held in the 1970s from the House of Commons Library's 'UK election statistics: 1918-2019' with various indicators of rural poverty, conflict and inequality in the $1820 \mathrm{~s}, 1830 \mathrm{~s}$ and $1870 \mathrm{~s}^{25}$

The 1820s and 1830s represent a period of rural poverty and intense rural conflict in parts of England, including significant poor relief expenditure and the Swing Riots. We use three indicators: poor relief expenditure; the Swing Riots; and an 1870 indicator of agrarian inequality. Regarding poor relief per head in the 1820 s and 1830s at the county level, we rely on Blaug (1963). The most authoritative quantitative study on the English Poor Law argues that poor relief expenditures in the period 1760 to 1815 were negatively correlated with access to land and positively correlated with winter unemployment rates (Boyer 1990, 38, 132). Secondly, we focus on the Swing Riots, as they mark the peak of rural conflict in nineteenth-century England. We have collapsed at the county level the parish-level data on riot events from Caprettini and Voth (2020). Rural discontent was correlated with the use of mechanical threshers, which severely depressed the winter employment prospects of rural labourers, suggesting that the Swing Riots were closely correlated with rural poverty and landlessness (Hobsbawm and Rudé 1968,

\footnotetext{
${ }^{25}$ The UK election data are available at: https://commonslibrary.parliament.uk/research-briefings/cbp-8647/
} 


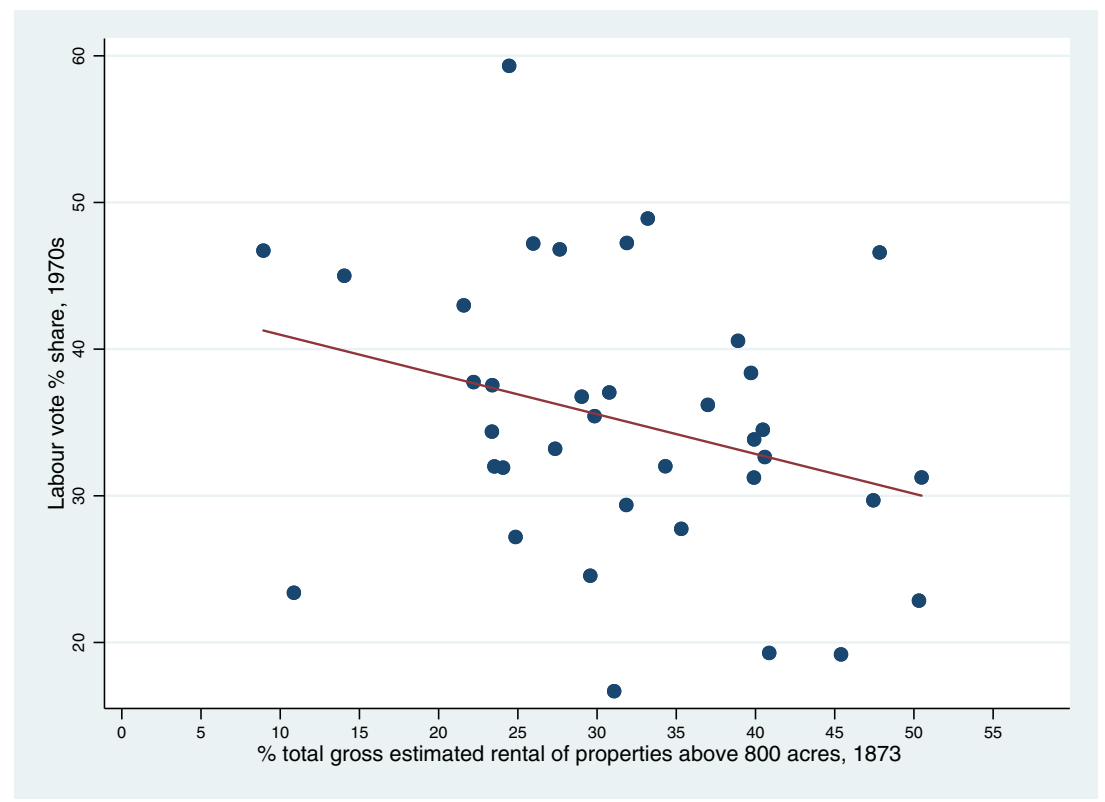

Fig. 5. Relationship between agrarian inequality and leftist vote in England.

359). ${ }^{26}$ The connection between rural poverty and rural conflict shows up in the positive correlation between the average number of Swing Riots at the county level and poor relief expenditure in 1831 (correlation is 0.41). Finally, we have used the 1873 Report of Owners of Land to construct county-level measures of agrarian inequality by calculating county-level measures of the share of total rents concentrated in the hands of owners of more than 800 acres (Great Britain Local Government Board 1875). By 1873, Britain (in this case, England) was already very urbanized, but the 1873 report is the only source that allows us to construct comparable measures of agrarian inequality with those we have for Spain in the nineteenth and twentieth centuries. The correlation between poor relief per head paid in 1831 and our 1873 measure of inequality is 0.3 .

In contrast to the Spanish or the Italian cases, past agrarian conflict and inequality in England is not associated with stronger support for the Left in the contemporary period. On the contrary, rural poverty and rural conflict are negatively correlated with leftist vote. In Figure 5, we plot the relationship between landownership inequality in 1873 and the average share of votes for Labour in the 1970s. The negative relationship is apparent in the figure, the correlation between the share of the Labour vote and the share of total rents going to owners of more than 800 acres in 1873 is -0.3 . Similarly, the correlation of leftist vote with poor relief per capita in 1831 is -0.37 , while the correlation with the mean number of Swing Riots is -0.17 . Therefore, there is either a negative or zero correlation between indicators of rural inequality, poverty or conflict and the Labour vote in the 1970s. Figures P1, P2 and P3 in the Online Appendix present scatter plots displaying the relationship between the various measures of rural poverty and conflict in the 1830s and the share of the Labour vote. The main conclusion of this analysis is that although England had a turbulent past of agrarian poverty, inequality and conflict, especially in the early 1830s, agrarian legacies do not explain the geography of Labour Party support there. When male suffrage became universal

\footnotetext{
${ }^{26}$ We drop the county of Rutland from the analysis and produce a weighted average for Yorkshire, combining the weighted averages of poor relief per capita and the Swing Riots in the East, West and North Ridings with weights taken from the population of each of these counties in 1831 according to the Population Census of Great Britain in 1831.
} 
after the First World War, rural conflict was not a salient issue, and, consequently, we see no trace of greater support for the Left in areas of higher agrarian inequality.

\section{Conclusions}

Although industrialization downplayed the relevance of the socio-structural element of the agrarian cleavage, the political allegiances that were part of the cleavage have survived until the contemporary period in some countries. To analyse this phenomenon, we have bridged the classical literature on cleavages and the burgeoning literature on historical legacies.

Given its troubled history during the twentieth century, including several regime breakdowns, a traumatic Civil War and a long dictatorial spell, Spain is one of the least auspicious countries in Western Europe for finding persistent political effects caused by old cleavages. Nonetheless, we have found a robust positive effect of pre-Civil War agrarian inequality on support for the Left in the contemporary democratic period (1977-2019).

The effect found in Spain is part of a larger pattern. Our argument establishes that similar effects should be found in other European countries that were late industrializers and had high agrarian inequality. By contrast, in early industrializers or in countries with a more egalitarian distribution of land, the effect should not exist. An exploratory analysis of Italy and England confirms these expectations: in Italy, we find a very similar effect to that of Spain, but not in England, the earliest industrializer in Europe. This opens the way for a more systematic and comparative investigation of the long-term consequences of the cleavage systems of the interwar period.

Supplementary Material. Online appendices are available at: https://doi.org/10.1017/S0007123421000387

Data Availability Statement. Replication data for this paper can be found in Harvard Dataverse at: https://doi.org/10.7910/ DVN/PZ9OMY

Acknowledgements. We thank Francisco Espinosa for sharing his data on Civil War violence and Daniel Oto-PeralÃas for sharing his data on the speed of the Reconquest. Paloma Aguilar and participants in the Carlos III-Juan March Institute of Social Sciences seminar provided invaluable feedback.

Financial Support. This research was supported by Spain's State Agency for Research (Agencia Estatal de Investigación [AEI]) (AEI grant PID2019-104869GB-100).

Competing Interests. None.

\section{References}

Acharya A, Blackwell M and Sen M (2016a) Explaining causal findings without bias: detecting and assessing direct effects. American Political Science Review 110(3), 512-529.

Acharya A, Blackwell M and Sen M (2016b) The political legacy of American slavery. The Journal of Politics 78(3), 621-641. Alvarez Tardío M and Villa R (2017) 1936: Fraude y Violencia en las Elecciones del Frente Popular. Madrid: Espasa Libros. Ansell BW and Samuels DJ (2014) Inequality and Democratization: An Elite-Competition Approach. Cambridge: Cambridge University Press.

Ayala F (2001) Las Elecciones en la Provincia de Cáceres durante la II República. Mérida: Editora Regional de Extremadura.

Baron RM and Kenny DA (1986) The moderator-mediator variable distinction in social psychological research: conceptual, strategic, and statistical considerations. Journal of Personality and Social Psychology 51(6), 1173-1182.

Bartolini S (2000) The Political Mobilization of the European Left, 1860-1980: The Class Cleavage. Cambridge Studies in Comparative Politics. New York, NY: Cambridge University Press.

Bartolini S and Mair P (1990) Identity, Competition and Electoral Availability: The Stabilisation of European Electorates 1885-1985. Cambridge: Cambridge University Press.

Baten J and Hippe R (2018) Geography, land inequality and regional numeracy in Europe in historical perspective. Journal of Economic Growth 23(1), 79-109.

Baten J and Juif D (2014) A story of large landowners and math skills: inequality and human capital formation in long-run development, 1820-2000. Journal of Comparative Economics 42(2), 375-401. 
Beltrán FJ and Martínez-Galarraga J (2018) Inequality and education in pre-industrial economies: evidence from Spain. Explorations in Economic History 69, 81-101.

Bentzen J, Sinding NK and Wingender AM (2013) The timing of industrialization across countries. Working Paper 13-17, University of Copenhagen, Denmark.

Bernal AM (1988) Economía e Historia de los Latifundios. Madrid: Espasa-Calpe.

Blaug M (1963) The myth of the old Poor Law and the making of the new. The Journal of Economic History 23(2), 151-184.

Boletín del Ministerio de Trabajo y Previsión Social. Issues 18 (January 1932) to 43 (February 1934).

Boletín del Ministerio de Trabajo, Sanidad y Previsión. Issues 44 (March 1934) to 51 (October 1934).

Boix C (2003) Democracy and Redistribution. Cambridge: Cambridge University Press.

Boyer GR (1990) An Economic History of the English Poor Law, 1750-1850. Cambridge: Cambridge University Press.

Broadberry S, Giordano C and Zollino F (2011) Un'analisi settoriale dello sviluppo italiano, 1861-2011. Working Paper 20, Banca d'Italia, Italy.

Caprettini B and Voth H-J (2020) Rage against the machines: labor-saving technology and unrest in industrializing England. American Economic Review: Insights 2(3), 305-320.

Carrión P (1975) Los Latifundios en España: su Importancia, Origen, Consecuencias y Solución. Barcelona: Ariel.

Charnysh V (2015) Historical legacies of interethnic competition: anti-Semitism and the EU referendum in Poland. Comparative Political Studies 48(13), 1711-1745.

Darden K and Grzymala-Busse A (2006) The great divide: literacy, nationalism, and the communist collapse. World Politics 59(1), 83-115.

Díaz del Moral J (1973) Historia de las Agitaciones Campesinas Andaluzas. Antecedentes para una Reforma Agraria. Madrid: Alianza.

Domenech J (2013) Rural labour markets and rural conflict in Spain before the Civil War (1931-6). The Economic History Review 66(1), 86-108.

Domenech J and Herreros F (2017) Land reform and peasant revolution. Evidence from 1930s Spain. Explorations in Economic History 64, 82-103.

Domènech J and Sánchez-Cuenca I (2021) Replication Data for: The Long Shadow of Agrarian Conflict: Agrarian Inequality and Voting in Spain. https://doi.org/10.7910/DVN/PZ9OMY, Harvard Dataverse, V1, UNF:6:vdW/zwThhu6+94uP/ eTwqQ $==[$ fileUNF $]$

Dirección General del Instituto Geográfico, Catastral y de Estadística (1932). Censo de la Población de España según el Empadronamiento Hecho en la Península e Islas Adyacentes y Posesiones del Norte y Costa Occidental de África el 31 de Diciembre de 1930. Madrid: Talleres del Instituto Geográfico y Catastral.

Espinosa F (2007) La Primavera del Frente Popular. Los Campesinos de Bajadoz y el Origen de la Guerra Civil (marzo-julio de 1936). Barcelona: Crítica.

Espinosa F (2010) Violencia Roja y Azul: España, 1936-1950. Barcelona: Crítica.

Ford R and Jennings W (2020) The changing cleavage politics of Western Europe. Annual Review of Political Science 23(1), 295-314.

Garrido L (1979) Colectividades Agrarias en Andalucía: Jaén (1931-1939). Madrid: Siglo XXI.

Great Britain Local Government Board (1875) Return of Owners of Land, 1873. London: George Edward Eyre and William Spottiswoode.

Herrera A and Markoff J (2012) Rural movements and the transition to democracy in Spain. Mobilization: An International Quarterly 16(4), 455-474.

Hobsbawm EJ and Rudé G (1968) Captain Swing. New York, NY: Pantheon.

Homola J, Pereira MM and Tavits M (2020) Legacies of the Third Reich: concentration camps and out-group intolerance. American Political Science Review 114(2), 573-590.

INE (Instituto Nacional de Estadística) (1986) Censo de 1787 'Floridablanca'. Madrid: Instituto Nacional de Estadística.

Jennings MK (1984) The intergenerational transfer of political ideologies in eight Western nations. European Journal of Political Research 12(3), 261-276.

Jennings MK, Stoker L and Bowers J (2009) Politics across generations: family transmission reexamined. The Journal of Politics 71(3), 782-799.

Kaplan T (1977) Anarchists of Andalusia, 1868-1903. Princeton, NJ: Princeton Legacy Library.

Linz JJ (1976) Patterns of land tenure, division of labor, and voting behavior in Europe. Comparative Politics 8(3), 365-430.

Linz JJ and Montero JR (2001) The party systems of Spain: old cleavages and new challenges. In Karvonen L and Kuhnle S (eds), Party Systems and Voter Alignments Revisited. London: Routledge, pp. 150-196.

Lipset SM and Rokkan S (1967) Cleavage structures, party systems, and voter alignments: an introduction. In Lipset SM and Rokkan S (eds), Party Systems and Voter Alignments: Cross-National Perspectives. New York, NY: Free Press, pp. 1-64.

Luebbert GM (1991) Liberalism, Fascism, or Social Democracy: Social Classes and the Political Origins of Regimes in Interwar Europe. New York, NY: Oxford University Press.

Lupu N and Peisakhin L (2017) The legacy of political violence across generations. American Journal of Political Science 61 (4), 836-851. 
Malefakis EE (1970) Agrarian Reform and Peasant Revolution in Spain. Origins of the Civil War. New Haven, CT: Yale University Press.

Manow P (2015) Workers, farmers and Catholicism: a history of political class coalitions and the South-European welfare state regime. Journal of European Social Policy 25(1), 32-49.

Maravall JM (1982) The Transition to Democracy in Spain. London: Croom Helm.

Maurice J (1990) Anarquismo Andaluz: Campesinos y Sindicalistas, 1868-1936. Barcelona: Crítica.

Moore B (1967) Social Origins of Dictatorship and Democracy: Lord and Peasant in the Making of the Modern World. Boston, MA: Beacon Press.

Orwell G (1962) Homage to Catalonia and Looking Back on the Spanish War. Middlesex: Penguin Books.

Oto-Peralías D (2020) Frontiers, warfare and economic geography: the case of Spain. Journal of Development Economics 146, 102511.

Oto-Peralías D and Romero-Ávila D (2016) The economic consequences of the Spanish Reconquest: the long-term effects of medieval conquest and colonization. Journal of Economic Growth 21(4), 409-464.

Quirosa-Cheyrouze R and Martos E (2019) La Transición desde otra Perspectiva. Democratización y Mundo Rural. Madrid: Sílex.

Rodden J (2019) Why Cities Lose: The Deep Roots of the Urban-Rural Political Divide. New York, NY: Basic Books.

Sanchez-Cuenca I (2019) The Historical Roots of Political Violence: Revolutionary Terrorism in Affluent Countries. Cambridge: Cambridge University Press.

Simpser A, Slater D and Wittenberg J (2018) Dead but not gone: contemporary legacies of communism, imperialism, and authoritarianism. Annual Review of Political Science 21(1), 419-439.

Simpson J and Carmona J (2020) Why Democracy Failed: The Agrarian Origins of the Spanish Civil War. Cambridge: Cambridge University Press.

Tilley J (2015) 'We don't do god'? Religion and party choice in Britain. British Journal of Political Science 45(4), 907-927.

Tur-Prats A (2019) Family types and intimate partner violence: a historical perspective. The Review of Economics and Statistics 101(5), 878-891.

Urwin DW (1980) From Roughshare to Ballotbox. The Politics of Agrarian Defence in Europe. Oslo: Universitetsforlaget.

Vanhanen T (2003) Democratization: A Comparative Analysis of 170 Countries. London: Routledge.

Vansteelandt S (2009) Estimating direct effects in cohort and case-control studies. Epidemiology 20(6), 851-860.

Ventura R (2001) Family political socialization in multiparty systems. Comparative Political Studies 34(6), 666-691.

Voigtländer N and Voth H-J (2012) Persecution perpetuated: the medieval origins of anti-Semitic violence in Nazi Germany. The Quarterly Journal of Economics 127(3), 1339-1392.

Wittenberg J (2006) Crucibles of Political Loyalty: Church Institutions and Electoral Continuity in Hungary. New York, NY: Cambridge University Press.

Ziblatt D (2008) Does landholding inequality block democratization? A test of the 'bread and democracy' thesis and the case of Prussia. World Politics 60(4), 610-641.

Ziblatt D (2017) Conservative Parties and the Birth of Democracy. Cambridge: Cambridge University Press.

Cite this article: Domènech J, Sánchez-Cuenca I (2022). The Long Shadow of Agrarian Conflict: Agrarian Inequality and Voting in Spain. British Journal of Political Science 52, 1668-1688. https://doi.org/10.1017/S0007123421000387 